\title{
Pleomorphic Hyalinizing Angietactic Tumors: Recognizing a Novel Source of Cancer in the Upper Extremity
}

\author{
Johnny Ionut Efanov*, Katherine Larose, Anne-Julie Labrecque and Michèle Tardif \\ University of Montreal, Canada
}

Submission: August 22, 2017; Published: August 30, 2017

*Corresponding author: Johnny Ionut Efanov, MD MSc, Division of Plastic Surgery at University of Montreal, Maisonneuve-Rosemont Hospital, 5415 Boulevard de L'Assomption, Montréal, Québec, H1T2M4, Canada, Tel: 1-514-252-3400; Email: johnny.ionut.efanov@umontreal.ca

\begin{abstract}
Soft tissue masses of the upper extremity often represent benign pathological entities, but the astute hand surgeon should use precaution when the possibility of malignancy arises. In the differential diagnosis, one needs to consider pleomorphic hyalinizing angiectactic tumors (PHAT), a novel pathology with increasing reports in the literature. The aim of this study is to report a case of PHAT in the hand and to describe diagnostic findings and management options. In the literature review, there were 11 patients with PHAT described in the upper extremity, occurring mostly in men, ranging from 4 to 26 centimetres in largest diameter with clinical findings significant for pain on direct palpation in the majority of cases. Treatment strategies included surgical excision with wide resection margins $(91 \%)$ and radiotherapy $(9 \%)$. There were no reported cases of recurrence in the upper extremity.
\end{abstract}

Keywords: Pleomorphic hyalinizing angiectatic Tumor; Hand

\section{Introduction}

A 60-year-old truck driver, right-handed, presented with a non-traumatic slow-growing mass on the palm of his left hand. He reported that the mass appeared 3 years prior to consultation, but he failed to seek a medical advice because it did not bother him. The mass slowly grew and started to become painful on palpation. He was referred for excisional biopsy by his family physician because the mass demonstrated signs of inflammation and was extremely painful. Upon presentation, he did not complain of any other symptoms, including fever or signs of systemic illness. On history, he denied smoking, medication use, allergies or a family history of tumors.

On hand examination, a large subcutaneous, non-mobile mass overlying the proximal wrist crease and abutting the proximal radial border of the hypothenar eminence was palpated (Figure 1). The largest superficial diameter of the lesion was $4.5 \mathrm{~cm}$. Neurovascular signs of the hand and fingers were normal and active and passive range of motion was unaffected. Upper extremity and axillary examination revealed no lymphadenopathy. 3-view x-rays radiography did not show any calcium deposits or ossifications in the tumor and underlying carpal-metacarpal bones were unaffected. Soft tissue swelling on the palmar side suggested a mass effect. Magnetic resonance imaging (MRI) was performed and demonstrated a polylobulated, $4.3 \times 1.4 \mathrm{~cm}$ mass in the subcutaneous soft tissue lying on the superficial palmar aponeurosis. There were no extensions into the hypothenar muscle or the carpal tunnel. There was no suggestive sign of abscess or necrotic material. Based on those findings, excisional biopsy seemed to be an appropriate option because a sarcoma was unlikely. 

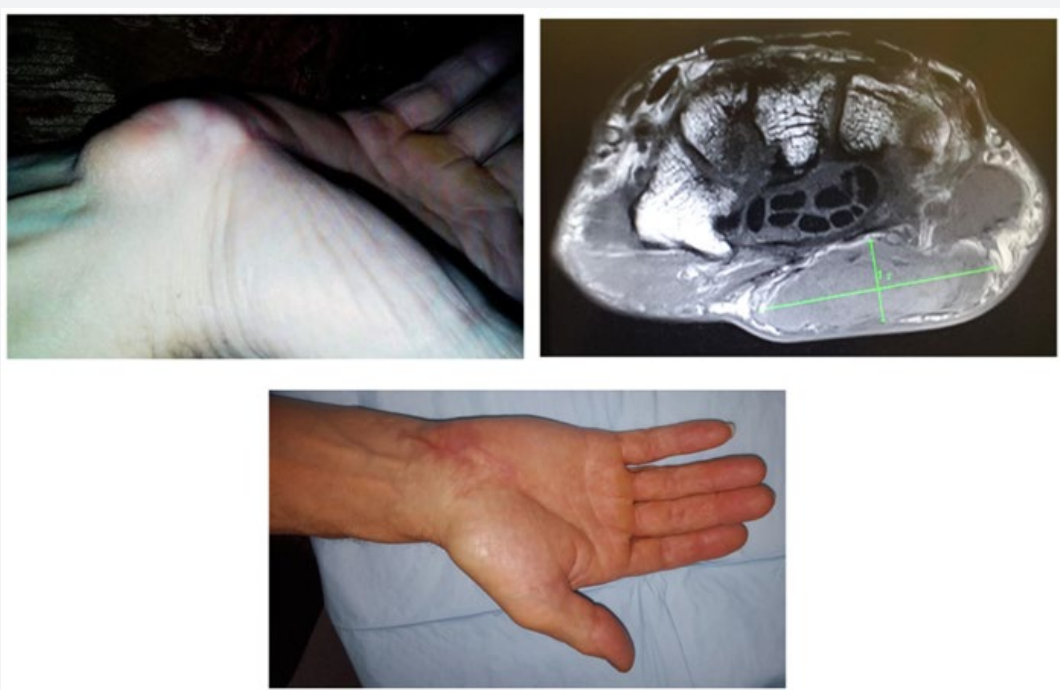

Figure 1: (Upper) Findings on physical examination demonstrated a large subcutaneous, non-mobile mass overlying the proximal wrist crease and abutting the proximal radial border of the hypothenar eminence. (Middle) Magnetic resonance imaging revealed a palmar subcutaneous poly-lobulated soft tissue mass without extensions. (Lower) Results at 18 months without any signs of recurrence.

Excisional biopsy with wide resection margins was an appropriate option in light of these findings. Regional anaesthesia was performed with a Bier block and an aseptic technique was employed. An elliptical skin incision over the carpal tunnel was performed. Surgical dissection of soft tissue surrounding the mass was undertaken, ensuring that wide margins of over $1 \mathrm{~cm}$ in all directions were taken. Skin closure was performed primarily using non-absorbable 3-0 sutures. The pathology report revealed a multi-lobed tumor lesion, moderately cellular, and with several vessel ectasia with hyalinised walls. Neoplastic cells were partly fusi form with moderate atypia, and partly pleomorphic with a large multi-lobed hyperchromatic nucleus. Several cells contained hemosiderin deposits. The stroma was partly hyalinised and some calcifications were present. Mitotic activity was low, between 0-2 mitoses per 50 fields at high magnification. Immunohistochemistry demonstrates a positive marking for Vimentine, a focal marking with Desmine and absence of marking to CD34, S100 protein, keratin AE1-AE3 and FVIII. Final diagnosis based on pathology findings indicated that the lesion corresponded to a pleomorphic hyalinizing angiectatic tumor (PHAT). Surgical treatment proved to be sufficient, avoiding the need for chemotherapy or radiotherapy postoperatively. No signs of recurrence are noted after 18 months of follow-up.

\section{Discussion}

Table 1: Systematic review of the literature for publications reporting PHAT in the upper extremity.

\begin{tabular}{|c|c|c|c|c|c|c|c|c|c|c|c|}
\hline Study & Year & Sex & Age & $\begin{array}{c}\text { Hand } \\
\text { Dominance }\end{array}$ & Site & $\begin{array}{l}\text { Preoperative } \\
\text { Duration }\end{array}$ & $\begin{array}{c}\text { Tumor } \\
\text { Size }\end{array}$ & $\begin{array}{c}\text { Clinicalsigns/ } \\
\mathbf{S x}\end{array}$ & $\begin{array}{l}\text { Imaging } \\
\text { Findings }\end{array}$ & Treatment & $\begin{array}{c}\text { Local } \\
\text { Recurrence }\end{array}$ \\
\hline \multirow[t]{4}{*}{ Folpe and Weiss [3] } & 2004 & M & 32 & NA & Arm & Unknown & $6,0 \mathrm{~cm}$ & NA & NA & NA & NA \\
\hline & & $\mathrm{F}$ & 39 & & Hand & Unknown & Unknown & & & NA & NA \\
\hline & & M & 42 & & Forearm & Manyyears & Unknown & & & $\begin{array}{c}\text { SE, } \\
\text { Radiotherapy }\end{array}$ & $\begin{array}{c}\text { None at } 10 \\
\text { years }\end{array}$ \\
\hline & & M & 67 & & Arm & Unknown & $5,8 \mathrm{~cm}$ & & & NA & NA \\
\hline $\begin{array}{c}\text { Parameshwarappa } \\
\text { et al. }\end{array}$ & 2010 & $\mathrm{~F}$ & 65 & NA & $\begin{array}{c}\text { Forearm } \\
\quad \mathrm{L}\end{array}$ & 13 years & $\begin{array}{c}5,0 \times 4,0 \\
\mathrm{~cm}\end{array}$ & $\begin{array}{c}\text { Intermittent } \\
\text { dull ache x } 3 \\
\text { years }\end{array}$ & NA & SE & $\begin{array}{c}\text { None at } 5 \\
\text { years }\end{array}$ \\
\hline Subhawong et al. & 2012 & $\mathrm{~F}$ & 87 & NA & Arm R & 3 years & $\begin{array}{c}4,8 \times 4,6 \mathrm{x} \\
5,8 \mathrm{~cm}\end{array}$ & $\begin{array}{l}\text { Intermittent } \\
\text { pain } \\
\text { ameliorated } \\
\text { with } \\
\text { repositioning }\end{array}$ & $\begin{array}{l}\text { Multiloculated } \\
\text { cystic mass } \\
\text { with nodular } \\
\text { and thickened } \\
\text { enhancing } \\
\text { septa }\end{array}$ & SE & $\begin{array}{c}\text { None at } 7 \\
\text { months }\end{array}$ \\
\hline Changchien et al. & 2014 & M & 76 & NA & Arm L & 5 months & $\begin{array}{c}4,6 \times 4,5 \mathrm{x} \\
3,0 \mathrm{~cm}\end{array}$ & None & NA & SE & $\begin{array}{c}\text { None at } 2 \\
\text { months }\end{array}$ \\
\hline
\end{tabular}




\begin{tabular}{|c|c|c|c|c|c|c|c|c|c|c|c|}
\hline Brazio et al. & 2015 & M & 22 & $\mathrm{R}$ & $\begin{array}{c}\text { Forearm } \\
\mathrm{R}\end{array}$ & 2 years & $\begin{array}{c}16,7 \mathrm{x} \\
24,2 \mathrm{x} \\
26,0 \mathrm{~cm}\end{array}$ & $\begin{array}{l}\text { Pain, Arm } \\
\text { weakness }\end{array}$ & $\begin{array}{c}\text { Cystic and/ } \\
\text { or necrotic } \\
\text { areas and } \\
\text { linear areas } \\
\text { representing } \\
\text { hemorrhage } \\
\text { or soft-tissue } \\
\text { components }\end{array}$ & SE & NA \\
\hline Michal et al. & 2016 & M & 63 & NA & Forearm & NA & $\begin{array}{c}4,0 \times 3,5 \times \\
2,5 \mathrm{~cm}\end{array}$ & NA & NA & SE & NA \\
\hline Kane et al. & 2016 & M & 35 & $\mathrm{R}$ & Hand R & Manyyears & $\begin{array}{c}4,6 \times 2,8 \times \\
1,8 \mathrm{~cm}\end{array}$ & $\begin{array}{c}\text { Painful with } \\
\text { power graps } \\
\text { and direct } \\
\text { pressure }\end{array}$ & $\begin{array}{c}\text { Consistent } \\
\text { with a lowflow } \\
\text { hemangioma }\end{array}$ & SE & NA \\
\hline Efanov et al. & 2016 & M & 60 & $\mathrm{R}$ & Hand L & 3 years & $\begin{array}{c}4,3 \times 1,4 \\
\mathrm{~cm}\end{array}$ & $\begin{array}{c}\text { Painfulwith } \\
\text { direct } \\
\text { pressure }\end{array}$ & $\begin{array}{c}\text { Polylobulated } \\
\text { without } \\
\text { abscess or } \\
\text { necrotic } \\
\text { material }\end{array}$ & SE & $\begin{array}{c}\text { None at } 18 \\
\text { months }\end{array}$ \\
\hline
\end{tabular}

Less than 100 cases of pleomorphic hyalinizing angiectatic tumors (PHAT) of soft tissue have been described to date [1], with growing awareness of the pathogenesis since the first descriptions by Smith in 1996 [2]. Risk factors and epidemiologic data remain under investigation, wherein most cases reported have demonstrated a preponderance for superficial soft tissues of the lower extremities, and occurring in both pediatric and adult populations [3]. We have conducted a review of the literature to expose all the cases of upper extremity PHATs, as it may be added to the actual differential diagnosis of soft tissue hand masses. Our results are found in Table 1. PHAT tumors were seen in the upper extremity of adults aged between 22 and 87 years old. The tumors were predominantly found in men (73\%) and occurred mostly in the arm or forearm, with only one case reported in the hand. Usually, growth of the mass occurs over extended periods of time and can reach dimensions as large as $26 \mathrm{~cm}$. Clinical signs are non-specific and patients usually complain of intermittent pain. Imaging studies usually demonstrate cystic masses with signs of hemorrhagic and necrotic areas.

Management options for PHAT are solely surgical for the time being, with no evidence of benefit from adjuvant chemotherapy or radiotherapy. There are no reports suggesting a metastatic potential, which is an encouraging prospect with regards to the pathophysiological aggressiveness of this cancer. Therefore, we believe that a large surgical excision with negative margins remains the best option when addressing PHAT [4]. In the literature, recurrence rates have been shown to be as much as $30-50 \%$, all of them following marginal excision, which reinstates the necessity for wider surgical margins $[3,5]$. Fortunately, there have been no cases of upper extremity recurrences [3]. One of the difficulties with pathological diagnosis of PHAT relies in its similarities with other sarcomas [6,7]. Indeed, undifferentiated sarcomas with fusi form or pleomorphic cells can resemble PHAT under microscope examination. Furthermore, our patient did not express CD34 which was often seen in other reports of PHAT
[8]. It is arguable that neo adjuvant treatment could be provided in the context of uncertainty between PHAT and a sarcomatous tumor. However, the safety of performing a wide surgical excision in the upper extremity seems to be sufficient with regards to the aggressiveness of this cancerous tumor.

\section{Acknowledgement}

We acknowledge contributions from Dr. Josée Doyon for pathological diagnosis of the tumor and Dr. Marie-Josée Berthiaume for preoperative imaging evaluation.

\section{References}

1. Changchien YC, Bocskai P, Kovacs I, Hargitai Z, Kollar S, et al. (2014) Pleomorphic hyalinizing angiectatic tumor of soft parts: case report with unusual ganglion-like cells and review of the literature. Pathol Res Pract 210(12): 1146-1151.

2. Smith ME, Fisher C, Weiss SW (1996) Pleomorphic hyalinizing angiectatic tumor of soft parts. A low-grade neoplasm resembling neurilemoma. Am J Surg Pathol 20(1): 21-29.

3. Folpe AL, Weiss SW (2004) Pleomorphic hyalinizing angiectatic tumor: analysis of 41 cases supporting evolution from a distinctive precursor lesion. Am J Surg Pathol 28(11): 1417-1425.

4. Lee JC, Jiang XY, Karpinski RH, Moore ED (2005) Pleomorphic hyalinizing angiectatic tumor of soft parts. Surgery 137(1): 119-121.

5. Suzuki K, Yasuda T, Hori T, Oya T, Watanabe K, et al. (2014) Pleomorphic hyalinizing angiectatic tumor arising in the thigh: A case report. Oncol Lett 7(4): 1249-1252.

6. Mitsuhashi T, Barr RJ, Machtinger LA, Cassarino DS (2005) Primary cutaneous myxofibrosarcoma mimicking pleomorphic hyalinizing angiectatic tumor (PHAT): a potential diagnostic pitfall. Am J Dermatopathol 27(4): 322-326.

7. Kazakov DV, Pavlovsky M, Mukensnabl P, Michal M (2007) Pleomorphic hyalinizing angiectatic tumor with a sarcomatous component recurring as high-grade myxofibrosarcoma. Pathol Int 57(5): 281-284.

8. Peng HC, Huang MT, Chen DJ, Leung TK, Chu JS (2010) Pleomorphic hyalinizing angiectatic tumor of soft parts. Journal of the Formosan Medical Association 109(8): 616-620. 
This work is licensed under Creative Commons Attribution 4.0 Licens DOI: 10.19080/JTMP.2017.02.555579.
Your next submission with Juniper Publishers will reach you the below assets

- Quality Editorial service

- Swift Peer Review

- Reprints availability

- E-prints Service

- Manuscript Podcast for convenient understanding

- Global attainment for your research

- Manuscript accessibility in different formats ( Pdf, E-pub, Full Text, Audio)

- Unceasing customer service

Track the below URL for one-step submission https://juniperpublishers.com/online-submission.php 